Article

\title{
Novel Pyridyl-Oxazole Carboxamides: Toxicity Assay Determination in Fungi and Zebrafish Embryos
}

\author{
Shu Chen, Dong-Lin Zhang, Chao-Li Ren, Wen-Qian Zou, Xiao-Yu Tian, Xiao-Hua Du and Cheng-Xia Tan * \\ College of Chemical Engineering, Zhejiang University of Technology, Hangzhou 310014, China; \\ omunyu@163.com (S.C.); z1076718730@163.com (D.-L.Z.); 18708589843@163.com (C.-L.R.); \\ zwqxyes@163.com (W.-Q.Z.); t895745887@163.com (X.-Y.T.); duxiaohua@zjut.edu.cn (X.-H.D.) \\ * Correspondence: tanchengxia@zjut.edu.cn; Tel./Fax: +86-571-8832-0238
}

Citation: Chen, S.; Zhang, D.-L.; Ren C.-L.; Zou, W.-Q.; Tian, X.-Y.; Du,

X.-H.; Tan, C.-X. Novel

Pyridyl-Oxazole Carboxamides: Toxicity Assay Determination in Fungi and Zebrafish Embryos. Molecules 2021, 26, 3883. https:// doi.org/10.3390/molecules26133883

Academic Editor: René Csuk

Received: 18 May 2021

Accepted: 21 June 2021

Published: 25 June 2021

Publisher's Note: MDPI stays neutral with regard to jurisdictional claims in published maps and institutional affiliations.

Copyright: (c) 2021 by the authors. Licensee MDPI, Basel, Switzerland. This article is an open access article distributed under the terms and conditions of the Creative Commons Attribution (CC BY) license (https:// creativecommons.org/licenses/by/ $4.0 /)$.

\begin{abstract}
Eight novel pyridyl-oxazole carboxamides were evaluated against fungi and displayed good fungicidal activities against Botrytis cinereal and Rhizoctonia solani. Preliminary bioassay results indicated that at $100 \mathrm{mg} / \mathrm{L}$, compounds $\mathbf{6 a}-\mathbf{6 e}, \mathbf{6 g}$ and $\mathbf{6 h}$ exhibited $100 \%$ fungicidal activities against Botrytis cinerea, and the compound $\mathbf{6 b}$ to Rhizoctonia solani at $100 \%$. Then, the zebrafish embryo acute toxicity test was performed to assess the toxicity of $\mathbf{6 b}$ and $\mathbf{6 c}$. A series of malformations appeared, when the zebrafish embryos were exposed to $\mathbf{6 b}$ and $\mathbf{6 c}$, such as delayed yolk sac resorption, significant shortening of body length, pericardial edema, bending spine, lack of melanin, heart hemorrhage, head hemorrhage, delayed swim sac development, yolk malformation and head malformation. In addition, the acute toxicity of $\mathbf{6 b}$ to zebrafish embryo is $4.878 \mathrm{mg} / \mathrm{L}$, and $\mathbf{6 c}$ is $6.257 \mathrm{mg} / \mathrm{L}$.
\end{abstract}

Keywords: oxazole; amide; pyridine; fungicide activity; toxicity

\section{Introduction}

In the early 20th century, pesticide, as a helpful partner for agriculture, came into our lives. Lots of people realized the fact that every coin has two sides: the effective pesticides may be hazardous to human health and the environment. In recent decades, the mushrooming human population has come with a booming economy, followed by the unexpected impact from the accumulation of environmental pollution caused by abusing pesticides. The residues of pesticides slipped into the food chain quietly, through bioconcentration and biomagnification, invisibly and continuously, affecting all natural creatures.

Since quality of life has improved, people have been concerned with the pesticide residues and setting higher demands on pesticides, including insecticides, herbicides, and fungicides. Currently, it is hard to imagine the world without pesticides, which have already permeated so many aspects of our lives. Thus, toxicological study of pesticides, by helping people directly and visually recognize the toxicity of pesticides, is absolutely significant. In recent years, because of certain inherent features, such as the comparable genetic and physiological make-up of mammals, zebrafish are widely used in toxicity research as an alternative model. Since zebrafish can absorb small molecules in their environment through skin and gills [1], their embryos and larvae were commonly used in developmental toxicity research to assess toxicity, such as cardiovascular toxicity, neurotoxicity and ototoxicity [2-4].

Along with social progress and the awakening of people's awareness of human health and environmental protection, many highly toxic pesticides were gradually eliminated by market forces, which urged researchers to search for ideal alternatives to those pesticides. Amide compounds with ideal biological activity and metabolic properties were widely used in insecticide and fungicide [5,6]. Additionally, in the process of creating green pesticides, heterocyclic pesticides have the characteristics of high activity and good selectivity, thus becoming one of the hot spots in the development of pesticide lead compounds [7-11]. Since the 20th century, many highly active amide-containing fungicidal drugs containing 
heterocyclic structures [12-15] have been developed (Figure 1). Nitrogen-containing heterocyclic compounds have various structural forms and good biological activity. Thus, the compound is widely used in the field of pesticides. At the same time, pyridine derivatives [16-21] and oxazole derivatives [22-27] (Figure 2) have also attracted attention as important nitrogen-containing heterocyclic compounds.<smiles>O=C(NCc1ncc(Cl)cc1Cl)c1c(Cl)cccc1Cl</smiles>

Fluopicolide<smiles>Cc1nn(C)c(Cl)c1C(=O)Nc1cccc2c1C(C)OC2(C)C</smiles>

Furametpyr<smiles>Cn1cc(C(=O)Nc2ccc(Br)cc2-c2ccc(Cl)c(Cl)c2)c(C(F)F)n1</smiles><smiles>Cc1nn(C)c(F)c1C(=O)Nc1ccccc1C(C)CC(C)C</smiles>

Figure 1. Chemical structures of Fluopicolide, Furametpyr, Bixafen and Penflufen.<smiles>COCOC(=O)C(C#N)=C(NCc1ccccc1OCc1coc(-c2ccc(F)cc2)n1)SC</smiles><smiles>COc1ccc(-c2cc(CNC(=O)c3cn(C)nc3C(F)F)on2)c(OC)c1OC</smiles>

Figure 2. Chemical structures of oxazole derivatives.

Chlorantraniliprole was used as the lead compound, relating to the phenylcyclobioxazole structure of oxazole derivatives, while the principle of bioelectronic isostery was used to obtain the pyridixazole structure, introduce the benzamide structure and, finally, design and synthesize several pyridines bioxazole amide compounds (Figure 3). The synthetic route is shown in Scheme 1. Furthermore, their fungicidal activities and toxicity test on zebrafish embryos were studied.

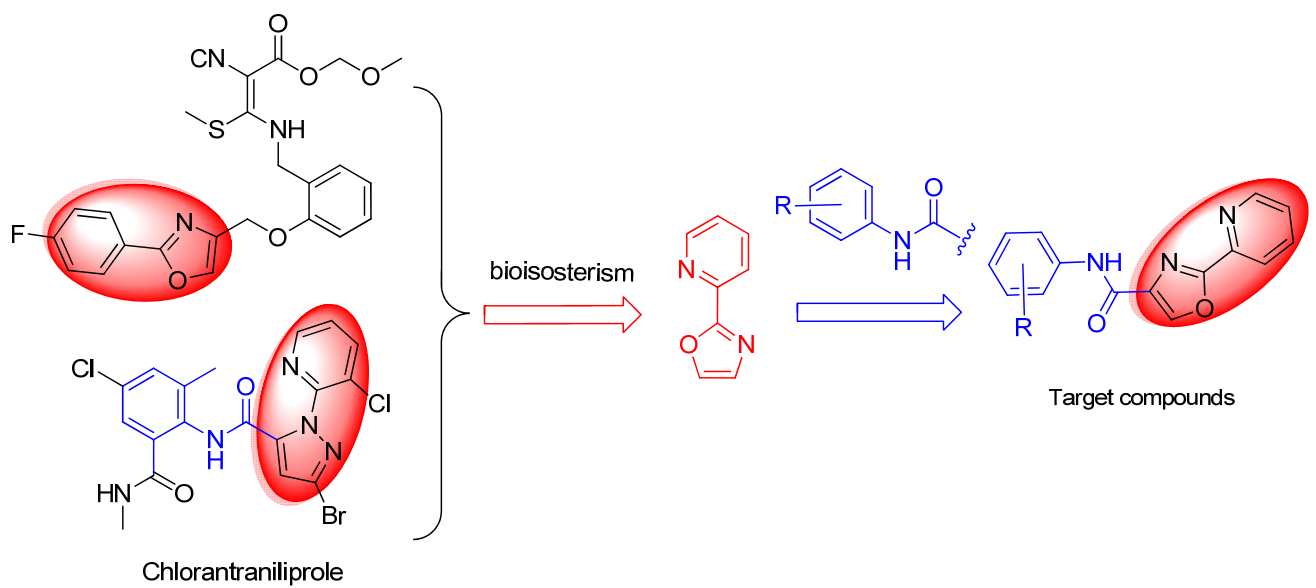

Figure 3. Design strategy of target compounds. 
<smiles>COC(=O)c1coc(-c2cccnc2)n1</smiles>

1

2 3

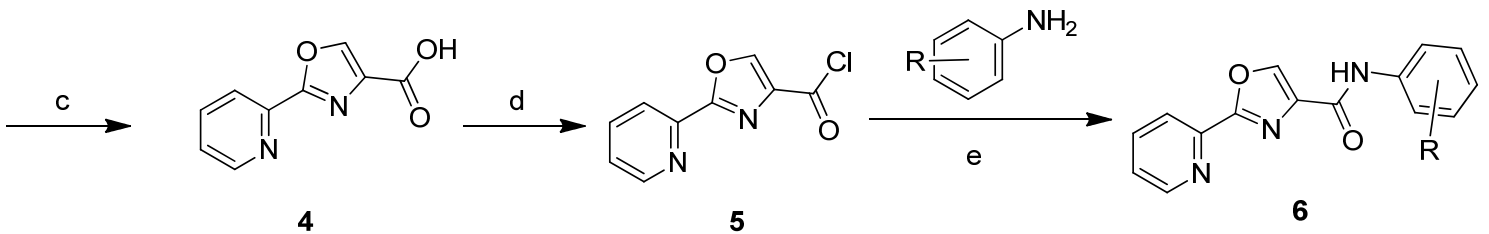

$\mathrm{R}=2-\mathrm{F}, 4-\mathrm{F}, 2,4-\mathrm{di}-\mathrm{F}$, etc.

Scheme 1. Synthetic route of target compounds. Reagents and conditions: (a) $\mathrm{CH}_{2} \mathrm{Cl}_{2}, \mathrm{Et} 3 \mathrm{~N}, \mathrm{Na}_{2} \mathrm{SO}_{4}, \mathrm{rt}$ for $10 \mathrm{~h}$ [28,29]; (b) $\mathrm{CH}_{2} \mathrm{Cl}_{2}, \mathrm{DBU}, \mathrm{CCl}_{3} \mathrm{Br}, 0^{\circ} \mathrm{C}$ for $12 \mathrm{~h} \mathrm{[29]}$; (c) $\mathrm{CH}_{3} \mathrm{OH}, \mathrm{OH}^{-}$, rt for $0.5 \mathrm{~h} ; \mathrm{H}^{+}$, rt for $1 \mathrm{~h}$; (d) $\mathrm{SOCl}_{2}, \operatorname{Reflux}$ for $2 \mathrm{~h}$; (e) $\mathrm{CH}_{2} \mathrm{Cl}_{2}$, $\mathrm{Et}_{3} \mathrm{~N}, \mathrm{rt}$ for $2 \mathrm{~h}$.

\section{Results and Discussion}

\subsection{Biological Activities of Target Compounds}

The fungicidal activity test results of the compounds $\mathbf{6 a}-\mathbf{6 h}$ against Botrytis cinereal and Rhizoctonia solani are shown in Tables 1 and 2. It can be seen that the target compounds had a high inhibitory effect on Botrytis cinereal, of which at a concentration of $100 \mathrm{mg} / \mathrm{L}, \mathbf{6 f}$ had a $90 \%$ inhibitory rate, and $\mathbf{6 a}-\mathbf{6 e}, \mathbf{6} \mathbf{g}$ and $\mathbf{6 h}$ were $100 \%$. Additionally, at a concentration of $100 \mathrm{mg} / \mathrm{L}$, the inhibition rates of $\mathbf{6 a}, \mathbf{6 e}$, and $\mathbf{6} \mathbf{h}$ against Rhizoctonia solani were $90 \%$, and $\mathbf{6 b}$ was $100 \%$. According to the data analysis in Tables 1 and 2, the results indicated that the inhibition rate of fluorine substitution was higher than that of chlorine substitution and methyl substitution when the benzene ring was substituted.

Table 1. Fungicidal activities (inhibition rate/\%) on Botrytis cinereal of compounds 6.

\begin{tabular}{|c|c|c|c|c|c|}
\hline \multirow{2}{*}{ Compd. } & \multirow{2}{*}{$\mathbf{R}$} & \multicolumn{4}{|c|}{ Botrytis cinereal } \\
\hline & & $100 \mathrm{mg} / \mathrm{L}$ & $50 \mathrm{mg} / \mathrm{L}$ & $25 \mathrm{mg} / \mathrm{L}$ & $12.5 \mathrm{mg} / \mathrm{L}$ \\
\hline $6 a$ & $2-\mathrm{F}$ & 100 & 45.88 & 12.36 & nt \\
\hline $6 b$ & $4-\mathrm{F}$ & 100 & 52.06 & 41.18 & 30.08 \\
\hline $6 c$ & 2,4-di-F & 100 & 63.83 & 40.30 & 29.71 \\
\hline $6 d$ & 2,6-di-F & 100 & 62.06 & 49.41 & 32.94 \\
\hline $6 e$ & $3-\mathrm{Cl}$ & 100 & 66.47 & 14.71 & nt \\
\hline $6 f$ & $3-\mathrm{Cl}-2-\mathrm{CH}_{3}$ & 90 & 65.00 & 44.71 & 17.36 \\
\hline $6 \mathrm{~g}$ & $4-\mathrm{CH}_{3}$ & 100 & 41.76 & 7.65 & 3.83 \\
\hline $6 h$ & 2,4 -di- $\mathrm{CH}_{3}$ & 100 & 64.41 & 28.83 & 7.06 \\
\hline \multicolumn{2}{|c|}{ Azoxystrobin } & 100 & 40 & 20 & 0 \\
\hline
\end{tabular}

Note: $\mathrm{nt}=$ not tested. All the data were determined three times.

Table 2. Fungicidal activities (inhibition rate/\%) on Rhizoctonia solani of compounds 6.

\begin{tabular}{|c|c|c|c|c|c|}
\hline \multirow{2}{*}{ Compd. } & \multirow{2}{*}{$\mathbf{R}$} & \multicolumn{4}{|c|}{ Rhizoctonia solani } \\
\hline & & $100 \mathrm{mg} / \mathrm{L}$ & $50 \mathrm{mg} / \mathrm{L}$ & $25 \mathrm{mg} / \mathrm{L}$ & $12.5 \mathrm{mg} / \mathrm{L}$ \\
\hline $6 a$ & $2-\mathrm{F}$ & 90 & 47.06 & 29.31 & 17.69 \\
\hline $6 b$ & $4-\mathrm{F}$ & 100 & 51.77 & 41.71 & 31.77 \\
\hline $6 c$ & 2,4-di-F & 80 & 79.12 & 18.24 & 16.77 \\
\hline $6 \mathrm{~d}$ & 2,6-di-F & 80 & 50.00 & 42.06 & 20.06 \\
\hline $6 e$ & $3-\mathrm{Cl}$ & 90 & 57.90 & 18.83 & 11.77 \\
\hline $6 f$ & $3-\mathrm{Cl}-2-\mathrm{CH}_{3}$ & 80 & 66.77 & 36.77 & 6.18 \\
\hline $6 \mathrm{~g}$ & $4-\mathrm{CH}_{3}$ & 70 & nt & nt & nt \\
\hline $6 \mathrm{~h}$ & 2,4 -di- $\mathrm{CH}_{3}$ & 90 & 55.30 & 34.41 & 4.41 \\
\hline \multicolumn{2}{|c|}{ Azoxystrobin } & 100 & 60 & 20 & 0 \\
\hline
\end{tabular}

Note: $\mathrm{nt}=$ not tested. All the data were determined three times. 
It can be seen from Tables 1 and 2 that at a concentration of $50 \mathrm{mg} / \mathrm{L}$, the inhibition rates of $\mathbf{6 c}(79.12 \%)$ and $\mathbf{6 f}(66.77 \%)$ on Rhizoctonia solani were better than azoxystrobin, and $\mathbf{6 c}-\mathbf{6 f}(62.06-66.47 \%)$ and $\mathbf{6 h}(64.61 \%)$ on Botrytis cinereal were better than azoxystrobin. According to the data in Table 2, it can be seen that at a concentration of $50 \mathrm{mg} / \mathrm{L}$, when the benzene ring was substituted, the inhibition rate of di-fluorine substitution was higher than mono-fluorine substitution against Rhizoctonia solani. On Botrytis cinereal, the inhibition rate of its di-substitution was higher than that of mono-substitution when the substituents on the benzene ring were fluorine and methyl.

\subsection{Toxicity to Zebrafish Embryos}

According to the data mentioned above, comparing their fungicidal activities, we chose compound $\mathbf{6 b}$ and $\mathbf{6 c}$ to study the lethal and teratogenic effects exposure on zebrafish embryos from 6 to $96 \mathrm{hpf}$.

At 24 hpf of $\mathbf{6 b}$ (Figure $4 \mathrm{~A}$ ), the autonomous movement of zebrafish embryo within 1 min was obviously inhibited, and there was a concentration-dependent effect. Among them, the 3 and $4 \mathrm{mg} / \mathrm{L}$ groups had a decrease in the autonomous movement of the embryo $(p<0.01)$, and in the 6 and $8 \mathrm{mg} / \mathrm{L}$ treatment groups, the number of autonomous movements of embryos was even less $(p<0.001$ ). At $48 \mathrm{hpf}$ (Figure 4B), compared to the control group, the hatching rate of the $6 \mathbf{b}$ drug-exposed group was significantly suppressed. At $72 \mathrm{hpf}$ (Figure 4B), under $\mathbf{6 b}$ concentration of $6 \mathrm{mg} / \mathrm{L}$, the hatching rate was about $5 \%$, and under $8 \mathrm{mg} / \mathrm{L}$ exposure, the hatching rate was $0 \%$. At $96 \mathrm{hpf}$ of $6 \mathbf{b}$ (Figure $4 \mathrm{C}$ ), the zebrafish malformation rate gradually increased with a concentration-dependency $(p<0.01$ and $p<0.001)$. The main phenotypic changes of zebrafish under $6 \mathbf{b}$ acute exposure (Figure 4E) were shortened body length, delayed tail development, delayed eye development, yolk cyst and even deformity, and there was a concentration-dependent effect. At the 48-96 hpf, a series of malformations appeared, such as delayed yolk sac resorption, significant shortening of body length, pericardial edema, bending spine, lack of melanin, heart hemorrhage, head hemorrhage, delayed swim sac development, yolk malformation and head malformation. The $\mathrm{LC}_{50}$ concentration of $\mathbf{6 b}$ (Figure $4 \mathrm{D}$ ) was $4.878 \mathrm{mg} / \mathrm{L}$.

The main manifestations of acute violent poisoning of $\mathbf{6 c}$ (Figure 4I) were yolk cyst, venous sinus hemorrhage, developmental delay, bending spine, hypopigmentation, pericardial cyst, and delayed swim sac development (represented by the black arrow). The pericardial edema was the most obvious. The hatching rate at $72 \mathrm{hpf}$ was shown in Figure 4F. At $8 \mathrm{mg} / \mathrm{L}$ and $16 \mathrm{mg} / \mathrm{L}$, the hatching rate was significantly reduced $(p<0.05, p<0.01$, $p<0.001$ ). The malformation rate at $96 \mathrm{hpf}$ was in Figure 4G. In the high-concentration exposure group, the malformation rate was significantly increased and showed a concentrationdependent $(p<0.001)$. Due to the impact of incubation and stillbirth, the mortality rate at $96 \mathrm{hpf}$ was counted (Figure $4 \mathrm{H}$ ), and the $\mathrm{LC}_{50}$ concentration was $6.257 \mathrm{mg} / \mathrm{L}$.

Comparing the lethal and teratogenic effects of $\mathbf{6 b}$ and $\mathbf{6 c}$, we found that the toxicity of $\mathbf{6 b}$ to zebrafish embryos was higher than that of $\mathbf{6 c}$. Therefore, we speculated that the structure of di-substitution was more beneficial than mono-substitution to reduce the toxicity to zebrafish embryos. 
A

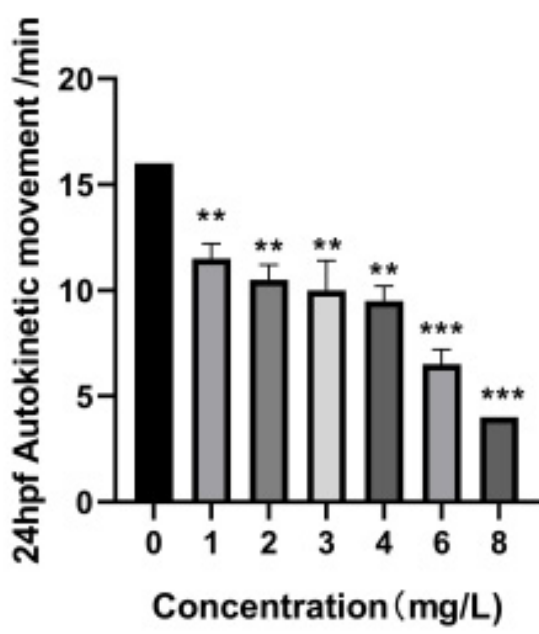

C

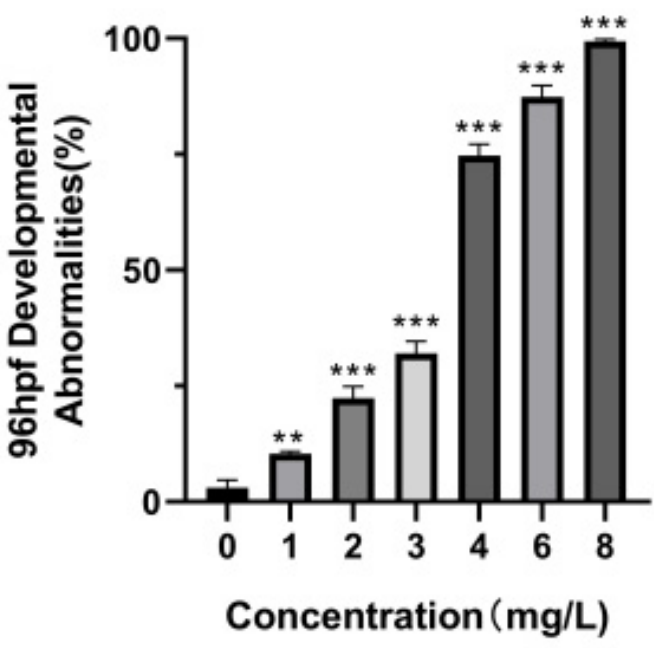

B

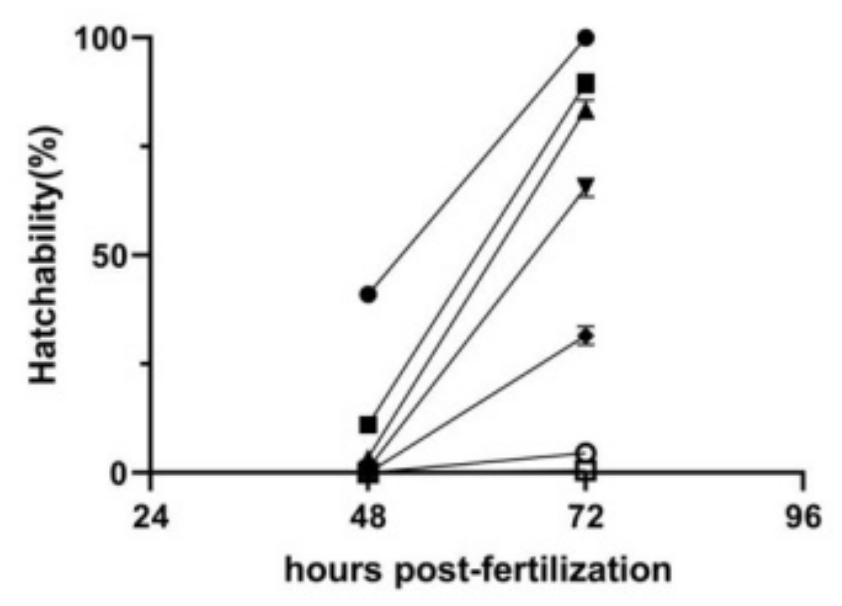

- Control

- $1 \mathrm{mg} / \mathrm{L}$

- $2 \mathrm{mg} / \mathrm{L}$

$\rightarrow 3 \mathrm{mg} / \mathrm{L}$

$\rightarrow 4 \mathrm{mg} / \mathrm{L}$

- $6 \mathrm{mg} / \mathrm{L}$

$8 \mathrm{mg} / \mathrm{L}$

$\mathrm{R}^{2}=0.9534 \quad \mathrm{LC}_{50}=4.878 \mathrm{mg} / \mathrm{L}$

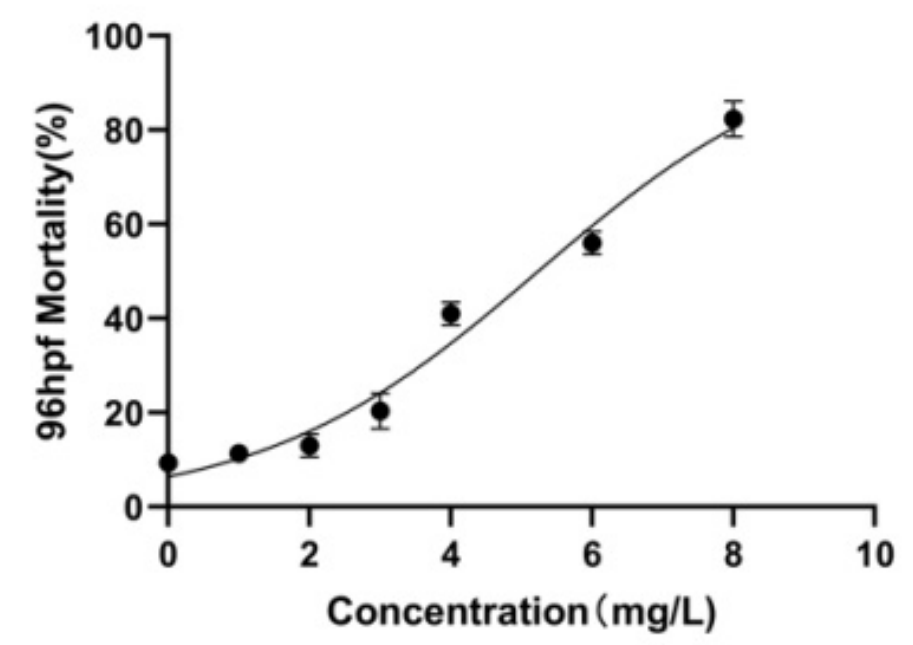

Figure 4. Cont. 
E

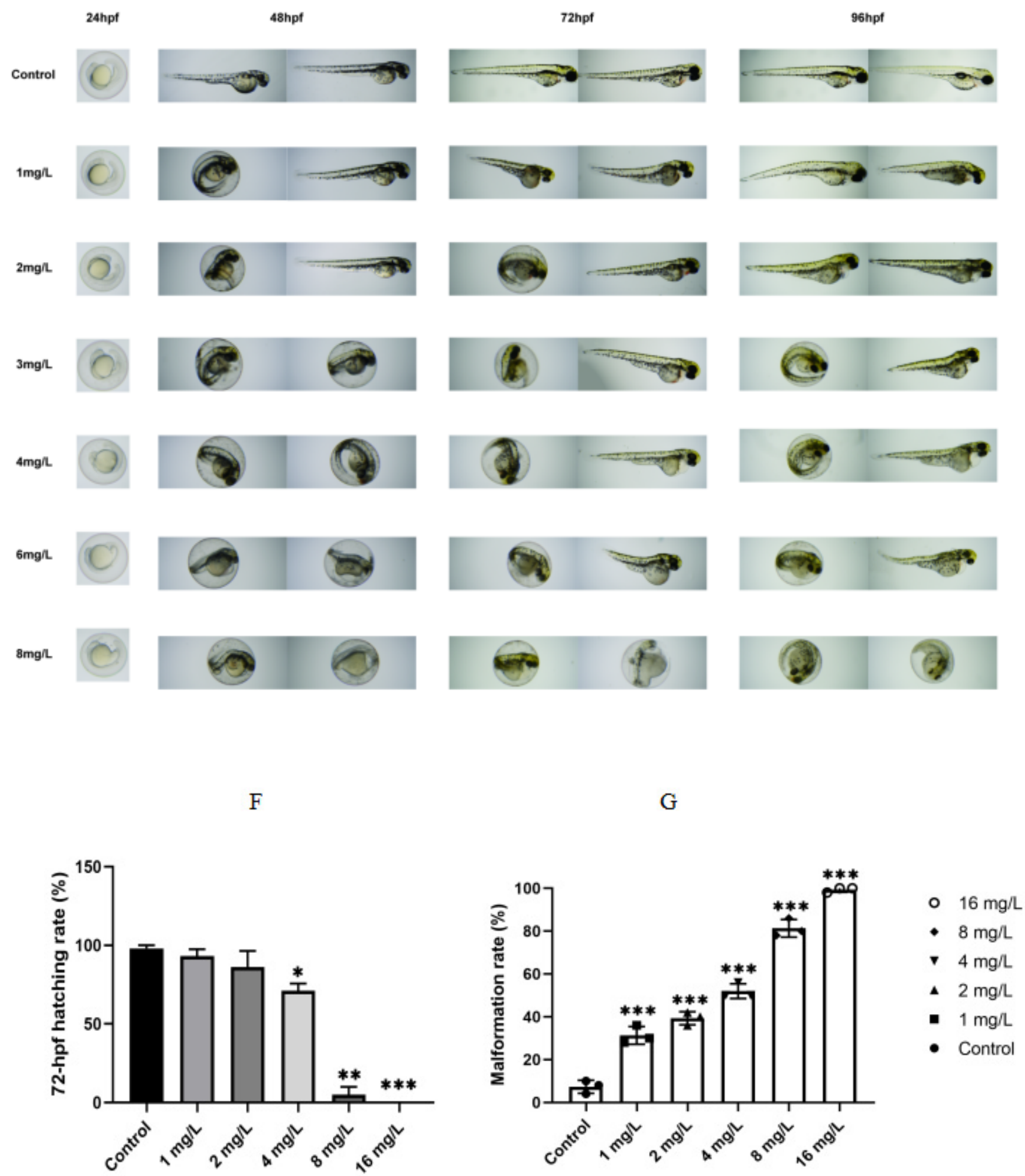

Figure 4. Cont. 


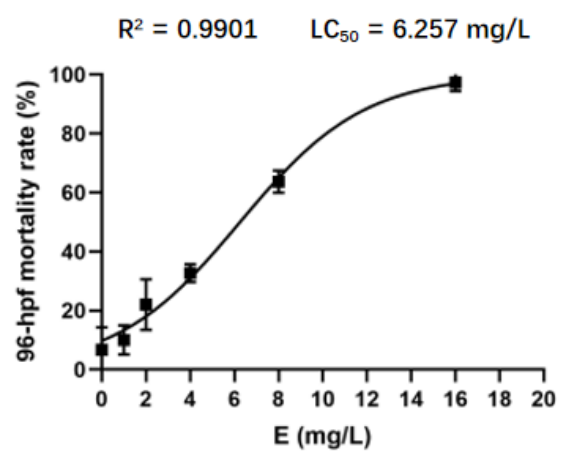

I

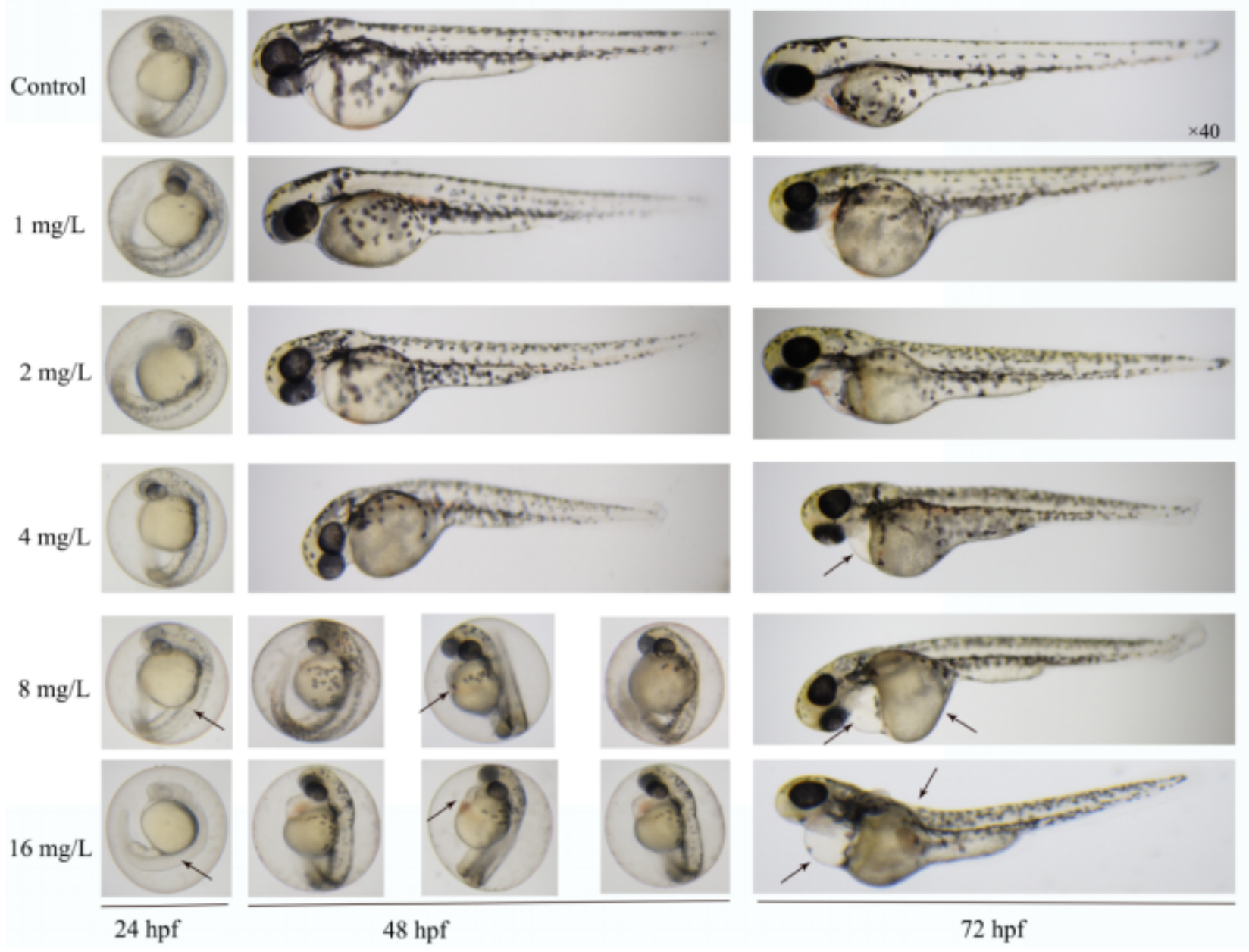

Figure 4. The effects of compound $\mathbf{6 b}$ and $\mathbf{6 c}$ exposure to zebrafish embryos. Note: (A) Zebrafish embryos autokinetic movement per minute after exposure to compound $\mathbf{6 b}$ from 6 to $24 \mathrm{hpf}$; (B) The hatchability of zebrafish embryos exposed to $\mathbf{6 b}$ from 24 to $96 \mathrm{hpf}$; (C) The developmental abnormalities of zebrafish embryos exposed to $\mathbf{6 b}$ at 96 hpf; (D) The mortality of zebrafish embryos exposed to $\mathbf{6 b}$ at $96 \mathrm{hpf}$; (E) The main phenotypic changes of zebrafish embryos and larvae under $\mathbf{6 b}$ exposure from 24 to $96 \mathrm{hpf}$ (F) The hatching rate of zebrafish embryos exposed to $6 \mathrm{c}$ at $72 \mathrm{hpf}$; (G) The malformation rate of zebrafish embryos and larvae under $\mathbf{6 c}$ exposure at $96 \mathrm{hpf} ; \mathbf{( H )}$ The mortality of zebrafish embryos exposed to $6 \mathrm{c}$ at 96 hpf; (I) The main phenotypic changes of zebrafish embryos and larvae under 6c exposure from 24 to 72 hpf. "** represents significant differences at $p \leq 0.05,{ }^{* *} p \leq 0.01$ and ${ }^{* *} p \leq 0.001$ by one-way ANOVA followed by a Dunnet test. 


\section{Materials and Methods \\ 3.1. Materials}

The compounds $\mathbf{6 a}-\mathbf{6 h}$ were confirmed by ${ }^{1} \mathrm{H}-\mathrm{NMR},{ }^{13} \mathrm{C}-\mathrm{NMR}$ and HRMS shown in Table 3. ${ }^{1} \mathrm{H}-\mathrm{NMR}$ and ${ }^{13} \mathrm{C}-\mathrm{NMR}$ spectra were measured on an NMR spectrometer (Bruker $500 \mathrm{MHz}$, Fallanden, Switzerland); high-resolution electrospray mass spectra (HRESI-MS) were determined using an UPLC H-CLASS/QTOF G2-XS mass spectrometer (Waters, Milford, MA, USA). In order to keep the compounds away from direct sunlight, the solutions of $\mathbf{6 b}$ (purity $\geq 98 \%$ ) and $\mathbf{6 c}$ (purity $\geq 98 \%$ ), prepared in tetrahydrofuran, were stocked in $-20{ }^{\circ} \mathrm{C}$ refrigeration. Additionally, diluted stock solutions were added in buffered zebrafish dechlorinated tap water $(\mathrm{pH}$ 6.5-7.5) to prepare nominal dosing solutions [30].

Table 3. ${ }^{1} \mathrm{H}-\mathrm{NMR},{ }^{13} \mathrm{C}-\mathrm{NMR}$ and HRMS of compounds $6 \mathrm{a}-6 \mathbf{h}$.

\begin{tabular}{|c|c|c|c|c|}
\hline Compd. & $\mathbf{R}$ & ${ }^{1} \mathrm{H}-\mathrm{NMR}$ & ${ }^{13} \mathrm{C}-\mathrm{NMR}$ & HRMS \\
\hline $6 a$ & $2-\mathrm{F}$ & $\begin{array}{c}{ }^{1} \mathrm{H}-\mathrm{NMR}\left(600 \mathrm{MHz}, \mathrm{DMSO}-d_{6}\right) \delta: 9.92(\mathrm{~s}, \\
1 \mathrm{H}, \mathrm{NH}), 8.98(\mathrm{~s}, 1 \mathrm{H}, \text { oxazole-H), } 8.77(\mathrm{~d}, \\
J=4.8 \mathrm{~Hz}, 1 \mathrm{H}, \mathrm{Py}-\mathrm{H}), 8.22(\mathrm{~d}, J=7.8 \mathrm{~Hz}, \\
1 \mathrm{H}, \mathrm{Py}-\mathrm{H}), 8.07(\mathrm{~m}, 1 \mathrm{H}, \mathrm{Py}-\mathrm{H}), 7.81-7.82 \\
(\mathrm{~m}, 1 \mathrm{H}, \mathrm{Ph}-\mathrm{H}), 7.62-7.63(\mathrm{~m}, 1 \mathrm{H}, \mathrm{Py}-\mathrm{H}) \\
7.34-7.35(\mathrm{~m}, 1 \mathrm{H}, \mathrm{Ph}-\mathrm{H}), 7.27-7.28(\mathrm{~m}, 2 \mathrm{H}, \\
\text { Ph-H) }\end{array}$ & $\begin{array}{c}{ }^{13} \mathrm{C}-\mathrm{NMR}\left(151 \mathrm{MHz}, \mathrm{DMSO}-\mathrm{d}_{6}\right) \delta: \\
160.4,158.9,156.3,154.6,150.6,145.1, \\
144.5,138.2,137.3,127.2(\mathrm{~d}, J=7.6 \mathrm{~Hz}), \\
126.3(\mathrm{~d}, J=26.0 \mathrm{~Hz}), 125.5(\mathrm{~d}, J=11.9 \\
\mathrm{Hz}), 125.0(\mathrm{~d}, J=3.3 \mathrm{~Hz}), 123.1,116.2 \\
(\mathrm{~d}, J=19.6 \mathrm{~Hz})\end{array}$ & $\begin{array}{c}\text { calcd for } \mathrm{C}_{15} \mathrm{H}_{11} \mathrm{FN}_{3} \mathrm{O}_{2} \\
\left([\mathrm{M}+\mathrm{H}]^{+}\right) 284.0830 \\
\text { found } 284.0822\end{array}$ \\
\hline
\end{tabular}

\begin{tabular}{|c|c|c|c|c|}
\hline $6 b$ & $4-F$ & $\begin{array}{c}{ }^{1} \mathrm{H}-\mathrm{NMR}\left(600 \mathrm{MHz}, \mathrm{DMSO}-\mathrm{d}_{6}\right) \delta: 10.32(\mathrm{~s}, \\
1 \mathrm{H}, \mathrm{NH}), 8.95(\mathrm{~s}, 1 \mathrm{H}, \text { oxazole-H), } 8.77(\mathrm{~d}, \\
J=4.8 \mathrm{~Hz}, 1 \mathrm{H}, \mathrm{Py}-\mathrm{H}), 8.23(\mathrm{~d}, J=8.0 \mathrm{~Hz}, \\
1 \mathrm{H}, \mathrm{Py}-\mathrm{H}), 8.07(\mathrm{td}, J=8.0,1.5 \mathrm{~Hz}, 1 \mathrm{H}, \\
\text { Py-H), } 7.84-7.87(\mathrm{~m}, 2 \mathrm{H}, \mathrm{Ph}-\mathrm{H}), 7.61-7.62 \\
(\mathrm{~m}, 1 \mathrm{H}, \mathrm{Py}-\mathrm{H}), \\
7.21(\mathrm{t}, J=9.0 \mathrm{~Hz}, 2 \mathrm{H}, \\
\text { Ph-H) }\end{array}$ & $\begin{array}{c}{ }^{13} \mathrm{C}-\mathrm{NMR}\left(151 \mathrm{MHz}, \mathrm{DMSO}-d_{6}\right) \delta: \\
160.28,159.79,158.97,158.19,150.58 \\
145.25,144.44,138.18,137.87,135.10 \\
126.28,123.01,123.0,122.9,115.70(\mathrm{~d} \\
J=22.1 \mathrm{~Hz})\end{array}$ & $\begin{array}{l}\text { calcd for } \mathrm{C}_{15} \mathrm{H}_{11} \mathrm{FN}_{3} \mathrm{O}_{2} \\
\left([\mathrm{M}+\mathrm{H}]^{+}\right) 284.0830 \\
\text { found } 284.0820\end{array}$ \\
\hline $6 c$ & $\begin{array}{c}\text { 2,4-di- } \\
\text { F }\end{array}$ & $\begin{array}{c}{ }^{1} \mathrm{H}-\mathrm{NMR}\left(500 \mathrm{MHz}, \mathrm{DMSO}-\mathrm{d}_{6}\right) \delta: 10.06(\mathrm{~s}, \\
1 \mathrm{H}, \mathrm{NH}), 8.97(\mathrm{~s}, 1 \mathrm{H}, \text { oxazole-H) } 8.77(\mathrm{~d}, \\
J=5.0,1 \mathrm{H}, \mathrm{Py}-\mathrm{H}), 8.21(\mathrm{~d}, J=8.0 \mathrm{~Hz}, 1 \mathrm{H}, \\
\text { Py-H), 8.06-8.07 (m, 1H, Py-H), 7.71-7.72 } \\
(\mathrm{m}, 1 \mathrm{H}, \mathrm{Ph}-\mathrm{H}), 7.61(\mathrm{q}, J=3.0 \mathrm{~Hz}, 1 \mathrm{H}, \\
\text { Py-H), 7.39-7.40 (m, 1H, Ph-H), } 7.14(\mathrm{t}, \\
J=4.5 \mathrm{~Hz}, 1 \mathrm{H}, \mathrm{Ph}-\mathrm{H})\end{array}$ & 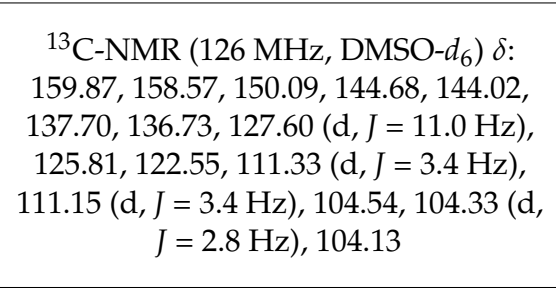 & $\begin{array}{c}\text { calcd for } \\
\mathrm{C}_{15} \mathrm{H}_{10} \mathrm{~F}_{2} \mathrm{~N}_{3} \mathrm{O}_{2} \\
\left([\mathrm{M}+\mathrm{H}]^{+}\right) 302.0736 \\
\text { found } 302.0731\end{array}$ \\
\hline $6 \mathrm{~d}$ & $\begin{array}{c}\text { 2,6-di- } \\
\text { F }\end{array}$ & $\begin{array}{c}{ }^{1} \mathrm{H}-\mathrm{NMR}\left(600 \mathrm{MHz}, \mathrm{DMSO}-\mathrm{d}_{6}\right) \delta: 10.03(\mathrm{~s}, \\
1 \mathrm{H}, \mathrm{NH}), 8.97(\mathrm{~s}, 1 \mathrm{H}, \text { oxazole-H), 8.77-8.79 } \\
(\mathrm{m}, 1 \mathrm{H}, \mathrm{Py}-\mathrm{H}), 8.21(\mathrm{~d}, J=7.8 \mathrm{~Hz}, 1 \mathrm{H}, \\
\text { Py-H), 8.06-8.07 (m, 1H, Py-H), 7.72-7.73 } \\
(\mathrm{m}, 1 \mathrm{H}, \mathrm{Ph}-\mathrm{H}), 7.61-7.63(\mathrm{~m}, 1 \mathrm{H}, \mathrm{Py}-\mathrm{H}) \\
7.39-7.41(\mathrm{~m}, 1 \mathrm{H}, \mathrm{Ph}-\mathrm{H}), 7.15-7.16(\mathrm{~m}, 1 \mathrm{H}, \\
\text { Ph-H) }\end{array}$ & $\begin{array}{c}{ }^{13} \mathrm{C}-\mathrm{NMR}\left(151 \mathrm{MHz}, \mathrm{DMSO}-d_{6}\right) \delta: \\
160.4,159.1,150.6,145.2,144.5,138.2 \\
137.2,128.2(\mathrm{~d}, J=9.5 \mathrm{~Hz}), 126.3,123.1 \\
111.7(\mathrm{dd}, J=22.1,3.5 \mathrm{~Hz}), 104.8(\mathrm{dd} \\
J=26.6,24.2 \mathrm{~Hz})\end{array}$ & $\begin{array}{c}\text { calcd for } \\
\mathrm{C}_{15} \mathrm{H}_{10} \mathrm{~F}_{2} \mathrm{~N}_{3} \mathrm{O}_{2} \\
\left([\mathrm{M}+\mathrm{H}]^{+}\right) 302.0736 \\
\text { found } 302.0726\end{array}$ \\
\hline $6 e$ & $3-\mathrm{Cl}$ & $\begin{array}{c}{ }^{1} \mathrm{H}-\mathrm{NMR}\left(600 \mathrm{MHz}, \mathrm{DMSO}-\mathrm{d}_{6}\right) \delta: 10.44(\mathrm{~s}, \\
1 \mathrm{H}, \mathrm{NH}), 8.98(\mathrm{~s}, 1 \mathrm{H}, \text { oxazole-H), } 8.77(\mathrm{~d}, \\
J=4.8 \mathrm{~Hz}, 1 \mathrm{H}, \mathrm{Py}-\mathrm{H}), 8.24(\mathrm{~d}, J=7.8 \mathrm{~Hz}, \\
1 \mathrm{H}, \mathrm{Py}-\mathrm{H}), 8.07-8.08(\mathrm{~m}, 1 \mathrm{H}, \mathrm{Py}-\mathrm{H}) \\
8.03-8.04(\mathrm{~m}, 1 \mathrm{H}, \mathrm{Ph}-\mathrm{H}), 7.80(\mathrm{~d}, J=8.2 \\
2.4 \mathrm{~Hz}, 1 \mathrm{H}, \mathrm{Ph}-\mathrm{H}), 7.62-7.63(\mathrm{~m}, 1 \mathrm{H}, \\
\text { Py-H), } 7.40(\mathrm{t}, J=8.2 \mathrm{~Hz}, 1 \mathrm{H}, \mathrm{Ph}-\mathrm{H}) \\
7.19-7.20(\mathrm{~m}, 1 \mathrm{H}, \mathrm{Ph}-\mathrm{H})\end{array}$ & $\begin{array}{c}{ }^{13} \mathrm{C}-\mathrm{NMR}(126 \mathrm{MHz}, \mathrm{DMSO}) \delta: 159.8 \\
158.8,150.1,144.7,144.2,139.8,137.7 \\
137.2,132.9,130.3,125.8,123.0,122.6 \\
120.0,118.9\end{array}$ & $\begin{array}{c}\text { calcd for } \\
\mathrm{C}_{15} \mathrm{H}_{11} \mathrm{ClN}_{3} \mathrm{O}_{2} \\
\left([\mathrm{M}+\mathrm{H}]^{+}\right) 300.0534 \\
\text { found } 300.0522\end{array}$ \\
\hline
\end{tabular}


Table 3. Cont.

\begin{tabular}{|c|c|c|c|c|}
\hline Compd. & $\mathbf{R}$ & ${ }^{1}$ H-NMR & ${ }^{13} \mathrm{C}-\mathrm{NMR}$ & HRMS \\
\hline $6 f$ & $\begin{array}{c}\text { 3-Cl-2- } \\
\mathrm{CH} 3\end{array}$ & $\begin{array}{c}{ }^{1} \mathrm{H}-\mathrm{NMR}\left(500 \mathrm{MHz}, \mathrm{DMSO}-\mathrm{d}_{6}\right) \delta: 10.15(\mathrm{~s}, \\
1 \mathrm{H}, \mathrm{NH}), 8.95(\mathrm{~s}, 1 \mathrm{H}, \text { oxazole-H) } \\
J=5.77(\mathrm{~d}, \\
\text { 1H, Py-H), } 8.07-8.08(\mathrm{~m}, 1 \mathrm{H}, \mathrm{Py}-\mathrm{H}), \\
7.62-7.63(\mathrm{~m}, 1 \mathrm{H}, \mathrm{Py}-\mathrm{H}), 7.43(\mathrm{dd}, J=7.8, \\
1.2 \mathrm{~Hz}, 1 \mathrm{H}, \mathrm{Ph}-\mathrm{H}), 7.38-7.39(\mathrm{~m}, 1 \mathrm{H}, \\
\mathrm{Ph}-\mathrm{H}), 7.26(\mathrm{t}, J=7.8 \mathrm{~Hz}, 1 \mathrm{H}, \mathrm{Ph}-\mathrm{H}), 2.28 \\
\left(\mathrm{~s}, 3 \mathrm{H}, \mathrm{CH}_{3}\right)\end{array}$ & $\begin{array}{c}{ }^{13} \mathrm{C}-\mathrm{NMR}(126 \mathrm{MHz}, \mathrm{DMSO}) \delta: 160.3 \\
159.1,150.6,145.2,144.4,138.2,137.6 \\
137.6,134.2,132.0,127.4,127.2,126.3 \\
125.7,123.0,15.7\end{array}$ & $\begin{array}{c}\text { calcd for } \\
\mathrm{C}_{16} \mathrm{H}_{13} \mathrm{ClN}_{3} \mathrm{O}_{2} \\
\left([\mathrm{M}+\mathrm{H}]^{+}\right) 314.0691 \\
\text { found } 314.0690\end{array}$ \\
\hline $6 g$ & 4-CH3 & $\begin{array}{c}{ }^{1} \mathrm{H}-\mathrm{NMR}\left(600 \mathrm{MHz}, \mathrm{DMSO}-\mathrm{d}_{6}\right) \delta: 10.12(\mathrm{~s}, \\
1 \mathrm{H}, \mathrm{NH}), 8.92(\mathrm{~s}, 1 \mathrm{H}, \text { oxazole-H), } 8.76(\mathrm{~d}, \\
J=4.2 \mathrm{~Hz}, 1 \mathrm{H}, \mathrm{Py}-\mathrm{H}), 8.24(\mathrm{~d}, J=7.8 \mathrm{~Hz}, \\
1 \mathrm{H}, \mathrm{Py}-\mathrm{H}), 8.06-8.07(\mathrm{~m}, 1 \mathrm{H}, \mathrm{Py}-\mathrm{H}), 7.70 \\
(\mathrm{~d}, J=8.4 \mathrm{~Hz}, 2 \mathrm{H}, \mathrm{Ph}-\mathrm{H}), 7.60-7.61(\mathrm{~m}, 1 \mathrm{H}, \\
\text { Py-H), } 7.17(\mathrm{~d}, J=17.2 \mathrm{~Hz}, 2 \mathrm{H}, \mathrm{Ph}-\mathrm{H}), 2.29 \\
\left(\mathrm{~s}, 3 \mathrm{H}, \mathrm{CH}_{3}\right)\end{array}$ & $\begin{array}{c}{ }^{13} \mathrm{C}-\mathrm{NMR}\left(151 \mathrm{MHz}, \mathrm{DMSO}-d_{6}\right) \delta: \\
160.2,158.8,150.6,145.3,144.2,138.2 \\
138.0,136.2,133.5,129.5,126.3,123.1 \\
121.0,21.0\end{array}$ & $\begin{array}{l}\text { calcd for } \mathrm{C}_{16} \mathrm{H}_{14} \mathrm{~N}_{3} \mathrm{O}_{2} \\
\left([\mathrm{M}+\mathrm{H}]^{+}\right) 280.1081 \\
\text { found } 280.1065\end{array}$ \\
\hline $6 h$ & $\begin{array}{l}\text { 2. 4-di- } \\
\text { CH3 }\end{array}$ & $\begin{array}{c}{ }^{1} \mathrm{H}-\mathrm{NMR}\left(500 \mathrm{MHz}, \mathrm{DMSO}-d_{6}\right) \delta: 9.73(\mathrm{~s}, \\
1 \mathrm{H}, \mathrm{NH}), 8.91(\mathrm{~s}, 1 \mathrm{H}, \text { oxazole-H), 8.76-8.78 } \\
(\mathrm{m}, 1 \mathrm{H}, \mathrm{Py}-\mathrm{H}), 8.22(\mathrm{~d}, J=8.0 \mathrm{~Hz}, 1 \mathrm{H}, \\
\text { Py-H), 8.06-8.08 (m, 1H, Py-H), 7.61-7.63 } \\
(\mathrm{m}, 1 \mathrm{H}, \mathrm{Py}-\mathrm{H}), 7.36-7.37(\mathrm{~m}, 1 \mathrm{H}, \mathrm{Ph}-\mathrm{H}) \\
7.10(\mathrm{~d}, J=2.0 \mathrm{~Hz}, 1 \mathrm{H}, \mathrm{Ph}-\mathrm{H}), 7.03(\mathrm{~d}, \\
J=8.0 \mathrm{~Hz}, 1 \mathrm{H}, \mathrm{Ph}-\mathrm{H}), 2.29\left(\mathrm{~s}, 3 \mathrm{H}, \mathrm{CH}_{3}\right) \\
2.23\left(\mathrm{~s}, 3 \mathrm{H}, \mathrm{CH}_{3}\right)\end{array}$ & $\begin{array}{c}{ }^{13} \mathrm{C}-\mathrm{NMR}\left(126 \mathrm{MHz}, \mathrm{CDCl}_{3}\right) \delta: 159.8 \\
158.3,150.1,144.8,143.4,137.6,137.4 \\
134.9,132.9,132.2,130.9,126.6,125.7 \\
125.3,20.5,17.6\end{array}$ & $\begin{array}{l}\text { calcd for } \mathrm{C}_{17} \mathrm{H}_{16} \mathrm{~N}_{3} \mathrm{O}_{2} \\
\left([\mathrm{M}+\mathrm{H}]^{+}\right) 294.1237 \\
\text { found } 294.1226\end{array}$ \\
\hline
\end{tabular}

\subsection{Fish Husbandry and Embryo Collection}

The zebrafish (D. rerio) used for the experiments were from the Institute of Hydrobiology. According to standard protocols, they were raised and adapted to the laboratory with a light/dark, $14 \mathrm{~h} / 10 \mathrm{~h}$ cycle in a circulation system with dechlorinated tap water $\left(\mathrm{pH}\right.$ 6.5-7.5) at a constant temperature $\left(27 \pm 0.5^{\circ} \mathrm{C}\right)$. In order to raise the conductivity to $450-1000 \mu \mathrm{S} / \mathrm{cm}$, the ocean salt was added to the water [30,31].

The eggs of the zebrafish that were acquired from spawning adults in tanks overnight, with a sex ratio of 2:2, were used for exposure experiments and collected within half an hour of light exposure [30]. By means of a stereomicroscope, the fertilized and normal embryos were inspected and staged for subsequent experiments. When at $6 \mathrm{hpf}$, they were distributed into 12-well plates [32] (10 embryos per well) for exposure, and three replicate experiments were performed.

\subsection{Ethics Statement}

The Institutional Animal Care and Use Committee (IACUC) at Wenzhou Medical University approved our study plan for the proper use of zebrafish. All studies were carried out in strict accordance with the guidelines of the IACUC. All dissections were performed on ice, and all efforts were made to minimize suffering.

\subsection{Fungicidal Activity and Toxicity Determination}

The fungicidal activity was investigated on the basis of reference [33], and the results were shown in Tables 1 and 2. Furthermore, compound $\mathbf{6 b}$ and $\mathbf{6 c}$ were selected to be assessed through the zebrafish embryo acute toxicity test. Based on the mortality rates of zebrafish, a series of gradient concentrations of the compound $\mathbf{6 b}$ and $\mathbf{6 c}$ were set according to the environmentally relevant concentrations and preliminary experiments.

Zebrafish embryos $(n=30)$ at $6 \mathrm{hpf}$ were selected under a stereomicroscope, and they were exposed to the compound $\mathbf{6 b}$ or $\mathbf{6 c}$ from 6 to $96 \mathrm{hpf}$ : control $(0 \mathrm{mg} / \mathrm{L}$ of $\mathbf{6 b}), 1,2,3,4$, $6,8 \mathrm{mg} / \mathrm{L}$ of $\mathbf{6 b}$; control $(0 \mathrm{mg} / \mathrm{L}$ of $\mathbf{6 c}), 1,2,4,8,16 \mathrm{mg} / \mathrm{L}$ of $\mathbf{6 c}$. The $\mathrm{LC}_{50}$ (median lethal 
concentration) values were computed by the Boltzmann equation [34,35]. The observational indexes included hatching rate, mortality rate and malformation rate.

\section{Conclusions}

In conclusion, the bioassay results indicated that at a concentration of $100 \mathrm{mg} / \mathrm{L}$, the target compound had a high inhibitory effect on Botrytis cinereal, of which $\mathbf{6 a}-\mathbf{6 e}, \mathbf{6 g}$ and 6h had a $100 \%$ inhibitory rate. Furthermore, most of the target compounds had a high inhibitory effect on Rhizoctonia solani. $\mathbf{6 b}(100 \%)$ had a high inhibition rate on Rhizoctonia solani. Additionally, the acute toxicity of compound $\mathbf{6 b}(4.878 \mathrm{mg} / \mathrm{L})$ and $\mathbf{6 c}(6.257 \mathrm{mg} / \mathrm{L})$ indicated that $\mathbf{6 b}$ and $\mathbf{6 c}$ exposure had an apparent influence on the normal development of the zebrafish process. By comparing their data, we also found that the toxicity of $6 \mathbf{b}$ to zebrafish embryos was higher than that of $\mathbf{6 c}$. Therefore, we could draw the conclusion that, compared with mono-substitution, the structure of di-substitution was more beneficial to reduce the toxicity to zebrafish embryos, which merits further study.

Author Contributions: S.C., D.-L.Z., C.-L.R., W.-Q.Z., X.-Y.T. carried out experimental work, S.C. prepared the manuscript, D.-L.Z. designed the material and supervised the project. X.-H.D. and C.X.T. revised the paper. All authors have read and agreed to the published version of the manuscript.

Funding: This work was funded by the Wynca Group and Siga Co. Ltd. R \& D Program, grant number KYY-HX-20180412 and KYY-HX-20180737.

Institutional Review Board Statement: The study was conducted according to the guidelines of the The Institutional Animal Care and Use Committee (IACUC) at Wenzhou Medical University and approved by the IACUC (SYXK (ZHE) 2020-0014).

Informed Consent Statement: Not applicable.

Data Availability Statement: The data presented in this study are available on request from the corresponding author.

Acknowledgments: We acknowledge Hui-Li Wang for supporting the toxicity determination.

Conflicts of Interest: The authors declare no conflict of interest.

Sample Availability: Samples of the compounds $6 \mathbf{b}$ and $6 c$ are available from the authors.

\section{References}

1. Hill, A.J.; Teraoka, H.; Heideman, W.; Peterson, R.E. Zebrafish as a model vertebrate for investigating chemical toxicity. Toxicol. Sci. 2005, 86, 6-19. [CrossRef]

2. Zhu, J.J.; Xu, Y.Q.; He, J.H.; Yu, H.P.; Huang, C.J.; Gao, J.M.; Dong, Q.X.; Xuan, Y.X.; Li, C.Q. Human cardiotoxic drugs delivered by soaking and microinjection induce cardiovascular toxicity in zebrafifish. J. Appl. Toxicol. 2014, 34, 139-148. [CrossRef]

3. Fan, C.Y.; Cowden, J.; Simmons, S.O.; Padilla, S.; Ramabhadran, R. Gene expression changes in developing zebrafish as potential markers for rapid developmental neurotoxicity screening. Neurotoxicol. Teratol. 2010, 32, 91-98. [CrossRef]

4. Ou, H.; Simon, J.A.; Rubel, E.W.; Raible, D.W. Screening for chemicals that affect hair cell death and survival in the zebrafish lateral line. Hear. Res. 2012, 288, 58-66. [CrossRef]

5. Yang, J.C.; Guan, A.Y.; Yang, F.; Liu, C.L. Progress of Fungicides in China and Abroad. Modern Agrochem. 2015, 14, 1-9.

6. Wu, Z.B.; Kuang, J.Q.; Yin, J.; Wu, S.X.; Cai, H. Synthesis and Antifungal Activity of Picolinamide Compounds. Guizhou Agric. Sci. 2013, 41, 93-94.

7. Kaspady, M.; Narayanaswamy, V.K.; Raju, M.; Rao, G.K. Synthesis, Antibacterial Activity of 2,4-Disubstituted Oxazoles and Thiazoles as Bioisosteres. Lett. Drug Des. Discov. 2009, 6, 21-28. [CrossRef]

8. Li, Y.; Zhang, H.Q.; Liu, J.; Yang, X.P.; Liu, Z.J. Stereoselective Synthesis and Antifungal Activities of (E)- $\alpha$-(Methoxyimino)benzeneacetate Derivatives Containing 1,3,5-Substituted Pyrazole Ring. J. Agric. Food Chem. 2006, 54, 3636-3640. [CrossRef] [PubMed]

9. Dai, H.; Zhuang, H.Y.; Shi, L.; Li, G.; Zhang, H.J.; Fang, Y.; Dai, B.J. Synthesis and Biological Activities of Novel Substituted Pyrazole Oximes Containing Substituted Pyridine Group. Chin. J. Org. Chem. 2015, 35, 2399-2404. [CrossRef]

10. Dai, H.; Li, Y.Q.; Du, D.; Qin, X.; Zhang, X.; Yu, H.B.; Fang, J.X. Synthesis and biological activities of novel pyrazole oxime derivatives containing a 2-chloro-5-thiazolyl moiety. J. Agric. Food Chem. 2008, 56, 10805-10810. [CrossRef]

11. Dai, H.; Li, H.; Jin, Z.C.; Liu, W.Y.; Xiao, Y.; He, H.B.; Wang, Q.M.; Shi, Y.J. Synthesis and Bioactivity of Novel 1-Methyl3-trifluoromethyl-5-subsituent-1H-pyrazole-4-carbaldehydeO-(4-trifluoromethylbenzoyl)oximes. Chin. J. Org. Chem. 2016, 36, 185-190. [CrossRef] 
12. Yang, Y.G.; Meng, S.Q.; Qi, Z.Q.; Ji, M.S.; Li, X.H. Synthesis and fungicidal activity evaluation of 2-thiazolyl amide cyclohexanesulfonamide. Chin. J. Pestic. Sci. 2018, 20, 287-293.

13. Wu, J.; Song, B.A.; Kang, S.D.; Yang, S.; Hu, D.Y. The Heterocyclic Amide Derivatives with Herbicidal Activity. Agrochemicals 2012, 51, 625-631.

14. Liu, X.H.; Zhao, W.; Shen, Z.H.; Xing, J.H.; Yuan, J.; Yang, G.; Xu, T.M.; Peng, W.L. Synthesis, nematocidal activity and docking study of novel chiral 1-(3-chloropyridin-2-yl)-3-(trifluoromethyl)-1H-pyrazole-4-carboxamide derivatives. Bioorg. Med. Chem. Lett. 2016, 26, 3626. [CrossRef]

15. Liu, X.H.; Zhao, W.; Shen, Z.H.; Xing, J.H.; Xu, T.M.; Peng, W.L. Eur. Synthesis, nematocidal activity and SAR study of novel difluoromethylpyrazole carboxamide derivatives containing flexible alkyl chain moieties. J. Med. Chem. 2017, 125, 881-889. [CrossRef]

16. Lahm, G.P.; Cordova, D.; Barry, J.D. New and selective ryanodine receptor activators for insect control. Bioorg. Med. Chem. 2009, 17, 4127-4133. [CrossRef]

17. Ji, W.J.; Xu, T.M.; Zheng, Z.W.; Zhu, B.C.; Li, J.; Hu, W.Q.; Kong, X.L. Synthesis and fungicidal activity of 1-(3-chloropyridin-2-yl)5-difluoromethyl-1H-pyrazole-4-carboxamide derivatives. Chin. J. Pestic. Sci. 2013, 15, 393-397.

18. Eryılmaz, S.; Çelikoğlu, E.T.; İdil, Ö.; İnkaya, E.; Kozak, Z.; Mısır, E.; Gül, M. Derivatives of Pyridine and Thiazole Hybrid: Synthesis, DFT, Biological Evaluation via Antimicrobial and DNA Cleavage Activity. Bioorg. Chem. 2020. [CrossRef] [PubMed]

19. Zhong, B.; Liu, C.L.; Zhao, W.G.; Li, Z.M. Synthesis and biological activity of multiple substituted pyridines and derivatives. Chin. J. Org. Chem. 2004, 24, 204.

20. Ouyang, G.P.; Cai, X.J.; Chen, Z.; Song, B.A.; Bhadury, P.S.; Yang, S.; Jin, L.H.; Xue, W.; Hu, D.Y.; Zeng, S. Synthesis and antiviral activities of pyrazole derivatives containing an oxime moiety. J. Agric. Food Chem. 2008, 56, 10160-10167. [CrossRef] [PubMed]

21. Wang, X.; Wang, C.Q.; Fu, C.R.; Zou, X.M. Synthesis and Herbicidal Activity of 2-Cyano-3-(2-substituted phenyoxypyridin-5-yl) Amino Acrylates Containing Substituted Phenoxyl Group. Chin. J. Org. Chem. 2015, 35, 92-99. [CrossRef]

22. Wang, M.M.; Zhang, Q.Q.; Yue, K.; Li, Q.S.; Xu, F.B. Synthesis and Insecticidal Activity of o-Carboxamidobenzamide Compounds Containing 2-(Substituted phenyl)oxazole Group. Chin. J. Org. Chem. 2017, 37, 1774-1780. [CrossRef]

23. Gideens, A.C.; Boshoff, H.I.M.; Franzblau, S.G.; Barry, C.E., III; Coppa, B.R. Antimycobacterial natural products: Synthesis and preliminary biological evaluation of the oxazole-containing alkaloid texaline. Tetrahedron Lett. 2005, 46, 7355-7357. [CrossRef]

24. Prakash, T.B.; Reddy, G.D.; Padmaja, A.; Padmavathi, V. Synthesis and antimicrobial activity of amine linked bis- and trisheterocycles. Eur. J. Med. Chem. 2014, 82, 347-354. [CrossRef]

25. Lin, J.; Chen, J.W.; Cai, X.Y.; Qiao, X.L.; Huang, L.P.; Wang, D.G.; Wang, Z. Evolution of Toxicity upon Hydrolysis of Fenoxapropp-ethyl. J. Agric. Food Chem. 2007, 55, 7626-7629. [CrossRef] [PubMed]

26. Shi, Y.J.; Du, X.C.; Wang, X.L.; Chen, Q.W.; Li, L.; Dai, H.; Xu, C.Q.; Zhang, J.Y.; Ling, Y. Synthesis and Herbicidal Activity of Novel Cyanoacrylate Derivatives Containing Substituted Oxazole Moiety. Chin. J. Org. Chem. 2018, 38, 1772-1778. [CrossRef]

27. Liu, T.T.; Ni, Y.; Zhong, L.K.; Huang, H.Y.; Hu, W.Q.; Xu, T.M.; Tan, C.X. Synthesis and Fungicidal Activity of Difluoromethy Substituted Carboxamide Derivatives. Chin. J. Org. Chem. 2015, 35, 422-427. [CrossRef]

28. Graham, T.H. A Direct Synthesis of Oxazoles from Aldehydes. Org. Lett. 2010, 12, 3614-3617. [CrossRef] [PubMed]

29. Credico, B.D.; Reginato, G.; Gonsalvi, L.; Peruzzini, M.; Rossin, A. Selective synthesis of 2-substituted 4-carboxy oxazoles, thiazoles and thiazolidines from serine or cysteine amino acids. Tetrahedron 2011, 67, 267-274. [CrossRef]

30. Zhang, Y.H.; Liu, M.; Liu, J.F.; Wang, X.D.; Wang, C.H.; Ai, W.M.; Chen, S.B.; Wang, H.L. Combined toxicity of triclosan, 2,4-dichlorophenol and 2,4,6-trichlorophenol to zebrafish ( Danio rerio ). Environ. Toxicol. Pharmacol. 2018, 57, 9-18. [CrossRef]

31. Liu, J.F.; Sun, L.M.; Zhang, H.Q.; Shi, M.R.; Dahlgren, R.A.; Wang, X.D.; Wang, H.L. Response mechanisms to joint exposure of triclosan and its chlorinated derivatives on zebrafish ( Danio rerio ) behavior. Chemosphere 2018, 193, 820-832. [CrossRef] [PubMed]

32. Colwill, R.M.; Creton, R. Locomotor behaviors in zebrafish (Danio rerio) larvae. Behav. Process. 2011, 86, 222-229. [CrossRef]

33. Zhang, Y.; Zhu, H.W.; Shang, J.F.; Wang, B.L.; Li, Z.M. Synthesis and Biological Activities of Novel 3-(((3-Bromo1-(3-chloropyridin2-yl)-1H-pyrazol-5-yl) methylene) amino)-substituted-benzo [d] [1,2,3] triazin-4(3H)-ones. Chin. J. Org. Chem. 2019, 39, 861-866. [CrossRef]

34. Chen, W.T.; Wang, Q.; Min, L.J.; Wu, H.K.; Weng, J.Q.; Tan, C.X.; Zhang, Y.G.; Hu, B.Z.; Liu, X.H. Synthesis, Crystal Structure, Fungicidal Activity, Molecular Docking, and Density Functional Theory Study of 2-Chloro-N-(p-tolylcarbamoyl) nicotinamide. Indian J. Heterocycl. Chem. 2019, 29, 429-435.

35. Zhang, Y.; Wang, X.; Yin, X.; Wang, H. Toxicity assessment of combined fluoroquinolone and tetracycline exposure in zebrafish (Danio rerio). Environ. Toxicol. Pharmacol. 2016, 31, 736-750. [CrossRef] [PubMed] 